\title{
Computing Technologies: A Cornerstone for Educational and Employment Equity
}

\section{MAURICE HOLLINGSWORTH}

\begin{abstract}
The rate of employment for people with disabilities is very low relative to employment levels of non-disabled people. One factor that appears to contribute to greater employment is the level of education achieved by the individual. The impact of higher levels of education on employment is reflected in the general population, but is particularly apparent in the statistics of people with disabilities. Unfortunately, disproportionately few people with disabilities take advantage of postsecondary education.

Technology is important for people with disabilities as a vehicle to education and eventually to employment. Computing technologies have been demonstrated as a powerful assistive tool to aid people with disabilities in an academic environment, especially as we are rapidly moving into the information age. These factors lead to the recommendation that we need to (a) provide "equity tools" for disabled students in postsecondary settings to enable access to computing technologies, (b) provide accompanying instruction and academic support, (c) educate students in the human services fields in the roles and processes of computing technologies, and (d) research and disseminate information on the equity tools and applications of these tools.
\end{abstract}

\section{Résumé}

Le taux d'emploi des personnes handicapées est très bas relativement au taux d'emploi des personnes non-handicapées. Un facteur qui semble contribuer au niveau d'emploi est l'éducation acquise par l'individu. L'impact de l'éducation sur l'emploi se reflète dans la population générale, mais se voit particulièrement dans les statistiques concernant les handicapées. Malheureusement, proportionnellement peu de personnes handicapées profitent de l'éducation postsecondaire.

La technologie est importante pour les personnes handicapées comme véhicule à l'éducation et éventuellement à l'emploi. Les technologies 
d'informatique ont été démontrées comme outils d'aide puissants aux gens défavorisés dans un milieu académique. Il est aussi reconnu que nous passons rapidement dans l'ère de l'information. Ces facteurs nous mènent à la recommandation qu'il faut (a) fournir des <<outils d'equité>> pour les élèves handicapés dans le milieu postsecondaire pour donner accès aux technologies d'informatique, (b) fournir ensemble instruction et support académique, (c) éduquer les élèves dans les domaines des services sociaux à propos des rôles et les procédures des technologies d'informatique, et (d) faire une recherche et une dissémination de l'information à propos de ces outils d'equité et de leurs applications.

The past decade has brought about revolutionary changes in access to powerful computing and information technologies. These technologies have had a profound effect on our education system and society as a whole. Not surprisingly, these same technologies are proving to be important tools for people with disabilities, particularly in the areas of employment and education. Computing technologies may offer a much needed scaffold for disabled people into the employment and educational arenas.

The meaning of the term "disability" varies considerably across authors and across time. In the current context the term refers to any restriction or lack of ability to perform an activity in a manner considered normal for a human being. The associated term "handicap" refers to a disability that results in a disadvantage for an individual that limits or prevents the fulfilment of a role that is normal for that individual. (World Health Organization, 1980). This definition is important, as it differentiates "disability" from "handicap", recognizing that although a disability may exist, a handicap is only present when a problem exists in the relationship between an individual and his or her environment.

\section{Employment of People with Disabilities}

A sizable proportion of our population lives with a disability. A recent Statistics Canada Survey estimates 2.4 million adult Canadians, 13 percent of the noninstitutionalized population aged 15 years and over, have some form of disability that interferes with daily living activities (Highlights from the Canadian Health and Disability Survey, 1985). The definition of disability used within this study includes seventeen categories of interference, such as: physical factors that limit long-term physical activity, the ability to walk upstairs, lift packages, read newsprint, or hear normal conversation. One and one-half million people with disabilities identified in this survey were between the ages of fifteen to sixty-four years, an age range that encompasses the majority of employed Canadians. 
In spite of the numbers of people with a disability, it was only during the past decade that many of the concerns of this group came to light. Recent legislation in the Canadian Parliament has addressed concerns of equity employment for people with disabilities and other minority groups. The Canadian Charter of Rights and Freedoms, Section 15(1) (Greene, 1989) underlines the requirement for equality rights for minorities in Canada and specifically includes people with a "mental or physical disability." One outgrowth of this type of legislation was the passage of Bill 62 (1986) which specifically addresses the need for equity employment. Under this bill, all federally regulated employers with 100 or more employees are required to develop an annual plan defining the implementation of an employment equity program. This plan is submitted to the Minister of Employment and Immigration and is available for public inspection (Coates, 1986).

Although the legislative pathways have been clearly marked, the stark reality remains. People with disabilities are largely unemployed. Having a disability has been a formidable barrier to finding and retaining a job in Canada. Although significant numbers of people with disabilities are employed, people with a disability are less likely to be working than their non-disabled counterparts. Gower (1988) indicates that 42 percent of disabled Canadians, between the ages fifteen to sixty-four years, were employed in 1984. In contrast, 67 percent of the non-disabled population in the same age range were employed. This difference in employment levels is socially significant, especially given the breadth of the definition of disability used within Gower's study. This difference in employment levels is even more exaggerated if one specifically examines trends among disabled women.

These are disturbing statistics in a society that places so much emphasis on the value of employment and the resulting economic and social benefits. Employment is crucial to functioning within our society. It offers two central benefits: a) a current income, and b) security for the future. Succinctly stated, employment offers the opportunity to earn a livelihood. However, it also offers numerous other benefits that many of us take for granted. Seminal work in the field of vocational counselling describes a breadth of benefits including the expression of one's personality (Holland, 1966); the development of human relations, recognition of one as a person, independence, self-control, status, and the opportunity for self expression (Super, 1957). Other authors describe further benefits: the validation of one's adult status, recognition of fulfilling a social role (Borow, 1979), ability utilization, opportunity for achievement, participation in decision making, social interaction (Suerko, 1989), and growth 
needs (Kulik, Olham, and Hackman, 1987). Some authors suggest that much of what we define as ourselves is defined in terms of our employment status.

\section{Educational Level and Employment}

Statistics offered by Gower (1988) strongly suggest that the level of one's education affects the likelihood of being employed. Individuals with postsecondary education are more likely to be employed than individuals with little or no education. This holds true for both men and women and is particularly apparent if one examines the employment statistics of people with disabilities, as illustrated in Figures 1 and 2.

Figure 1 highlights the effect of level of education on employment of women with and without disabilities. Disabled women with little or no education are not likely to be employed; only 28 percent of women in this category are under employment. In contrast, 69 percent of women with a disability, and who have a postsecondary education, are employed.

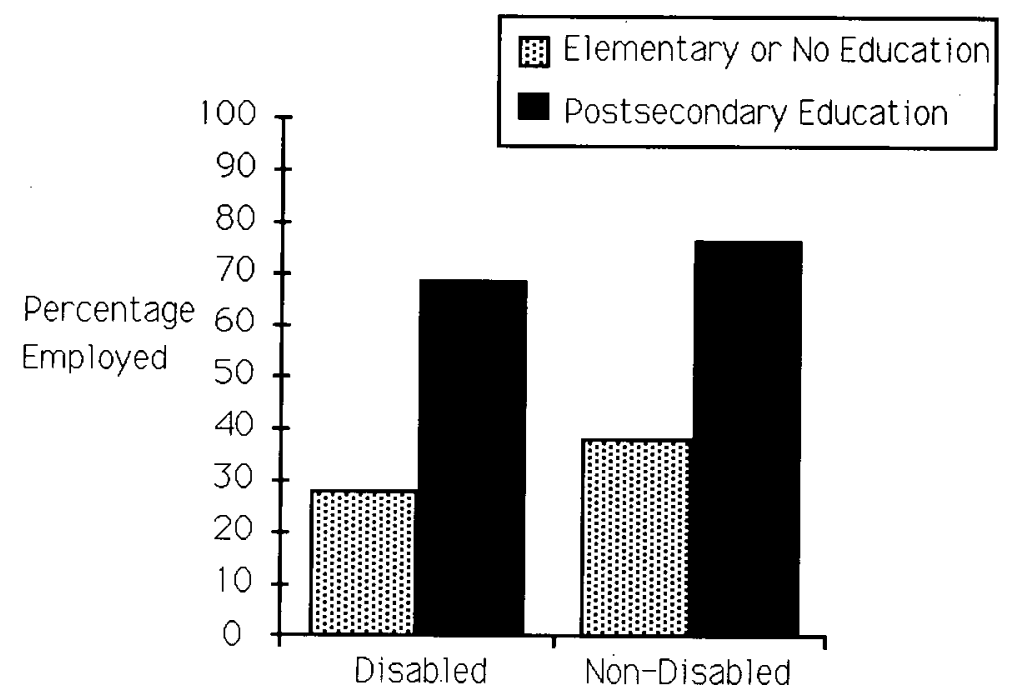

Figure 1. Effect of Level of Education on Disabled and Non-Disabled Women's Employment, 1984 (Statistics from Gower, 1988) 
This difference in employment levels of disabled persons, with differing levels of education, is even more pronounced if one examines the statistics of men with disabilities. Disabled men with little or no education are much less likely to be employed than their non-disabled counterparts with similar educational levels. Disabled men with a postsecondary education are almost equally likely to be employed as non-disabled men. As illustrated in Figure 2, only 33 percent of disabled men with low levels of formal education are employed. On the other hand, 78 percent of disabled men with a postsecondary education are employed - a difference of 45 percent.

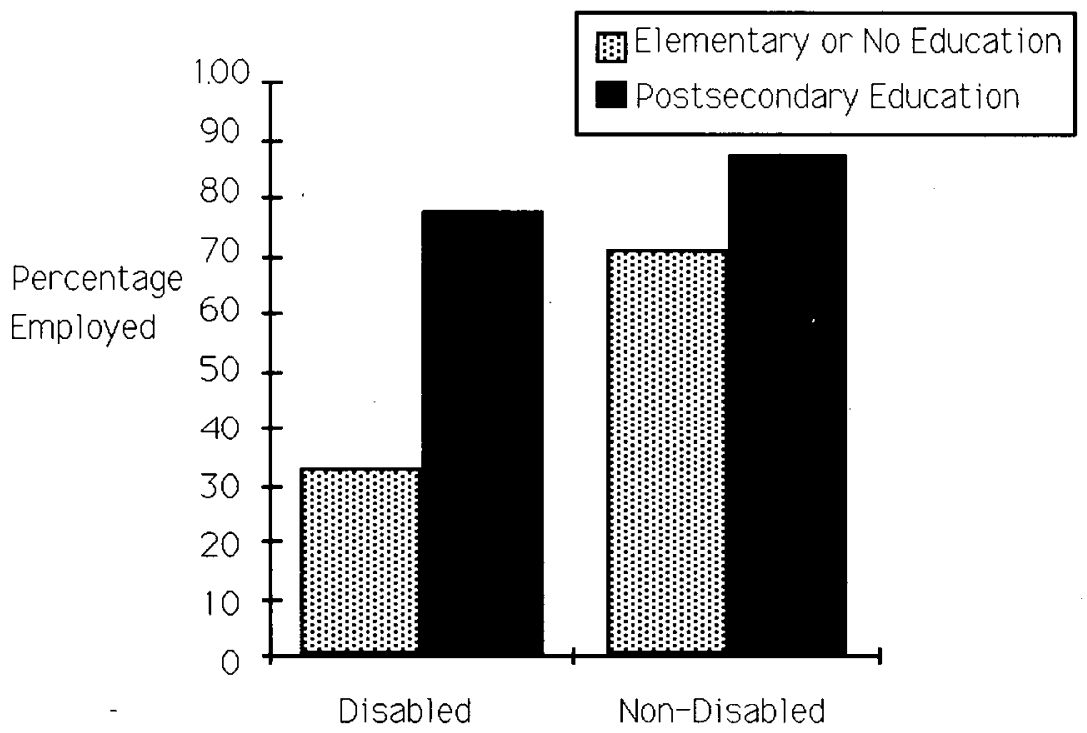

Figure 2. Effect of Level of Education on Disabled and Non-Disabled Men's Employment, 1984 (Statistics from Gower, 1988)

Higher levels of education are thus very important in enabling people with disabilities to achieve employment and hence attain other benefits associated with employment. Yet, in spite of the obvious benefit that higher education offers, universities tend to have a very low enrolment of people with disabilities. 


\section{People with Disabilities on Campus}

The enrolment of people with disabilities on Canadian campuses is disproportionate. This may be demonstrated by two different comparisons. First, one may compare the ratio of people with disabilities on campus to people with disabilities found in the general population. This type of comparison yields differing statistics depending on the source of information, but statistics from all information sources indicate that few people with disabilities are attending postsecondary institutions.

Calculations based upon information in the Directory of College Facilities and Services for the Handicapped (McGough, Jungjohan, \& Thomas, 1983) suggest that fewer than .5 percent of people attending forty-seven Canadian postsecondary institutions have a disability. The definition of disability in this directory is more restrictive than the Canadian Health and Disabilities Survey, primarily focusing on physical and sensory aspects of disability rather than on an environmental or functional definition.

Research in Highlights from the Canadian Health and Disabilities Survey (1985) similarly suggests that people with disabilities are not well-represented in postsecondary institutions. Conservative estimates suggest that 10 percent of the total population live with some form of disability. The Canadian Health and Disability Survey determined that 13 percent of the non-institutionalized population had one or more of the seventeen categories of disability (Gower, 1988). Yet, calculations based upon the same survey indicate that only 3 percent of all full time students have a disability.

The American President's Committee on Employment of the Handicapped reports that, if there were full participation of people with disabilities, approximately 8.5 percent of freshmen would be disabled (Higher Education \& National Affairs, 1987). In short, a fairly sizable portion of our population lives with a disability; yet a relatively small proportion of people who live with a handicap make up the postsecondary campus population.

A second comparison is made possible by contrasting statistics of disabled populations to non-disabled populations on campus. Statistics gathered in the Canadian Health and Disabilities Survey indicate that approximately 3 percent of all Canadians with disabilities, ages 15 years or older, are full-time students (Highlights from the Canadian Health and Disabilities Survey, 1985). This is in sharp contrast to 11 percent of non-disabled Canadians ages 15 years or older that are full-time students. Proportionally far fewer people with disabilities attend postsecondary institutions than their non-disabled counterparts. 
Given these statistics, it is not surprising that people with disabilities generally have not achieved levels of educational certification comparable to their non-disabled counterparts (Table 1). The completion rate of high school is relatively comparable for disabled and non-disabled people. However, at the postsecondary level differences between these groups begin to appear. Only 4.5 percent of people with disabilities complete some postsecondary work, while 9.1 percent of non-disabled people complete some education at this level (Highlights from the Canadian Health and Disabilities Survey, 1985). Similarly, 6.9 percent of people with disabilities complete a certificate or diploma program in a postsecondary stream, in contrast to 11.9 percent of people without disabilities. Finally, at the university level 3.9 percent of people with a disability complete a university degree. This is in contrast to 10.6 percent of the nondisabled population.

Table 1

Current Education Level of People with and without Disabilities.

(Based upon Highlights from the Canadian Health and Disabilities Survey, 1985)

\begin{tabular}{|c|c|c|c|c|}
\hline \multirow[b]{3}{*}{ High School Ed. } & \multicolumn{2}{|c|}{ Disabled } & \multicolumn{2}{|c|}{ Not Disabled } \\
\hline & $\begin{array}{l}\text { Total }^{\dagger} \\
\text { THOU }\end{array}$ & $\%$ & $\begin{array}{l}\text { Total }^{\dagger \dagger} \\
\text { THOU }\end{array}$ & $\%$ \\
\hline & 1007 & 41.1 & 8552 & 51.2 \\
\hline Some Postsecondary & 111 & 4.5 & 1511 & 9.1 \\
\hline $\begin{array}{l}\text { Postsecondary } \\
\text { certification/diploma }\end{array}$ & 168 & 6.9 & 1994 & 11.9 \\
\hline University Degree & 95 & 3.9 & 1763 & 10.6 \\
\hline $\begin{array}{l}\dagger_{n}=2,448,000 \\
\dagger_{n}=16,688,000\end{array}$ & & & & \\
\hline
\end{tabular}

In summary, approximately 23 percent of all non-disabled people complete a postsecondary certificate or university degree; only 11 percent of all disabled people attain the same level of education.

\section{Disability in the Information Age}

A base point for examining educational equity may be established by observing larger social and economic trends. As Toffler (1980) points out, we are moving from an industrial age into an information age. The industrial age was characterized by centralized controls, low skill requirements, repetitive work in 
centralized settings and the production of standardized goods. The information age is better characterized by decentralized decision-making, rapid rates of change, high degrees of specialization, and goods that are tailored to the individual or are offered with a breadth of variety. This movement away from the industrial age brings a new set of expectations. Members of society are expected to know and use the new tools and skills of the information age. To deny people with disabilities the opportunity to utilize information age technologies effectively compounds their level of handicap.

Two major types of tools are required by people with disabilities in the information age: standard productivity tools, and "equity tools". Standard productivity tools include common software and hardware combinations such as word processors, spelling checkers, grammar checkers, database systems, and spreadsheets. Other important productivity tools in this new era include graphing programs, multimedia presentation systems, drawing programs, and telecommunications systems. For the past several years, the skills required to use these basic computing tools have been in high demand (Bromley and Lakatos, 1985) as members of society have recognized the importance of such tools in their lives.

As Moursund (1986) points out, computers have changed the world we live in: through increased manufacturing using fewer workers; enhanced transportation, distribution and storage systems; and improved communications and telecommunications networks. Our educational needs also have changed as our world evolves into a new era. The National Education Association in the United States recently called for a computer on every teacher's desk by 1991 (Marks, 1989). If we encourage the majority of the population to study, have access to, and gain from the advantages of tools of the 21 st century (Alberta Education Technology in Education Committee, 1987), yet deny people with disabilities the same opportunities, we have certainly created a new handicapping condition.

Part of the solution is to provide equal access to technology through "equity tools." The term "equity tools" refers to those tools that are specifically designed to empower individuals with particular disabilities. Standard productivity tools and equity tools are not mutually exclusive. Equity tools are often built upon or are adjunct to productivity tools. For example, a speech synthesizer may be added onto a standard word processor, a word processor used by other nondisabled students; or the same speech synthesizer may verbalize information coming from a distant computer via a telecommunications network, the same network used by other nondisabled students. 
Equity tools are tailored to meet specific needs. They may be input devices, output devices, or software designed to meet specific needs of people with disabilities. Alternatively, they may be stand-alone systems that operate independently or, more ideally, link to other productivity tools. A breadth of equity tools exists. A recent issue of The Closing the Gap Resource Directory (1989) describes over 280 specialized hardware applications and over 800 software programs designed to meet special needs. The majority of such products did not exist a decade ago. This rapid growth of assistive technology is in some measure a testament to the interest in using technology to serve the needs of people with disabilities.

\section{Technology on Campus}

Numerous researchers and writers recognize the important role technology will play in education (Moursund, 1989; Marks, 1989; Alberta Education Technology in Education Committee, 1987). These authors generally agree that we are entering a new era in education, an era where technology will play an important role in preparing students for entry into an information age society. If people with disabilities hope to establish employment equity in this new era, they must have equal access to the tools and skills of the information age.

The role and potential of technology serving people with disabilities have been examined by various researchers. Irons (1985) describes a variety of equity tools that may benefit people with disabilities in education, communication, environmental control, recreation and vocation.

Keddy (1988) describes a number of adaptive devices and modifications designed to serve people with visual or orthopedic handicaps in postsecondary settings. The author underlines the importance of education and technology training as key factors in the employment of people who are blind or visually impaired. Seventy percent of visually impaired people of working age are not employed. In contrast, information in an American Foundation for the Blind database indicates that only 15 percent of more than 700 visually handicapped technology-users are unemployed.

One method of supporting individuals with disabilities within the academic environment has been to provide access to modern technologies in combination with academic support services. This combination has been demonstrated by Shell, Horn, and Severs (1988) to be an effective combination for improving disabled students' academic standing.

Research by Shell et al. specifically addressed the impact of computer use on disabled students' academic performance. The authors used an array of methods 
and measures to examine the effect of providing disabled students with (a) adaptations for computer access, (b) access to technology through laptop computers, (c) instructional services in the use of technology, and (d) academic support services. Students participating in the study were all postsecondary students utilizing services offered by "The Educational Centre for Disabled Students (ECDS)."

The primary goal of the centre was to enhance academic performance of disabled students. This goal was met by arranging access to computer hardware and software, computer support services, and academic support services. Adaptive devices were provided to enable access to computer systems and portable laptop computers. As well, some of these computers were provided as augmentative communication systems. Computer support services included training in the operation of computers, the operation of adaptive equipment, the use of software applications and the management of operating systems. Academic support services were offered through instruction in writing skills, study skills and language comprehension.

Prior to the start of the ECDS, traditional disabled student support services were offered in the form of classroom access, notetakers, extended testing time, and sign language interpretation. The new variable introduced in this study was access to computers, peripherals, and instruction in the use of these technologies to enable students with disabilities to meet the requirements of academic life.

The research conducted by Shell et al. examined several dependent variables including: (a) drop-out rate, (b) semester Grade Point Average (GPA), (c) cumulative GPA, and (d) percentage of students on academic suspension or probation.

Several evaluation designs were used in the study. One design compared two groups: (a) those students enrolled after the ECDS began offering service, and (b) those students enrolled prior to the start of the ECDS. Results on this comparison indicated that students who had received ECDS services had significantly higher semester and cumulative GPAs than students who were attending without ECDS services. Also, students who received ECDS services for their entire time in college had significantly fewer academic suspensions and probationary periods than disabled students who attended without ECDS services.

Another design in the study offered an analysis comparing the performance of disabled students to the performance of the general student population at the university. Although disabled students' cumulative GPA was lower than the GPA of the general population, a regression of results indicated that greater use 
of ECDS services was related to better academic performance. Before the initiation of ECDS services, the frequency of suspension and probation for disabled students was significantly higher than that for the general student population. After the first year of ECDS operations, however, the frequency of suspension and probation within the disabled student population was comparable to that of the general student population. Also, the attrition rate of students with disabilities decreased to a level equivalent to the general population after the first year of ECDS services.

Shell et al.'s research is one of few analytic studies that offer a detailed examination across several factors. This study suggests that technology can serve as an important tool for students with disabilities in an academic environment.

\section{Conclusion}

Given the recognition that technology will play an ever stronger role in the broader context of education, and in the much broader context of society at large, it seems apparent that we must begin examining how to utilize technology as a base for serving people with disabilities. Several recommendations spring forth: (a) we need to provide people with disabilities with equity tools; (b) we need to provide people with disabilities with a support structure to implement the use of these tools; (c) we need to educate graduates of postsecondary institutions to understand and use equity tools; and (d) we need to research products and processes to enhance equity tools and the implementation of these tools.

One method of dovetailing these recommendations is to provide a demonstration model of support technologies within postsecondary institutions. A demonstration model may have three primary objectives. First, such a centre would meet the immediate needs of students with disabilities entering the university environment. Technology resources need to be made available to people with disabilities, enabling them to gain access to technologies readily available to other students, as well as offering them a basic tool that will hold future value. Access to technology resources must be coupled with appropriate training and support services for the student. As demonstrated by Shell et al.'s research, the combination of equity tools, instruction in the use of equity tools, academic support services and follow-up services are an important blend to meet the academic needs of persons with disabilities.

Second, such a centre would educate students graduating from postsecondary institutions in technology applications in education, rehabilitation, and the human services field. Postsecondary institutions should offer instruction in the 
use of modern technologies to serve the needs of people with disabilities in the community at large. As human services professionals graduate and move out into the community, they should be prepared to enable people through modern technologies. These demonstration centres would offer excellent opportunities as practicum sites for students to understand the breadth of possibilities that equity tools may offer. As technologies continue to play an ever-increasing role in our lives, some depth of understanding of the field of computing technologies applications is necessary.

Third, these demonstration centres would conduct research and disseminate information on equity tools and their implementation. The technologies that serve people with disabilities are rapidly evolving. Consequently, a very real need exists for information to be attained through research and then disseminated. We need better to understand both the processes of implementing equity tools and equity tools themselves. Above all, we need to insist that equity tools be highly reliable and offer a similar degree of ease of use as standard computing tools. User interfacing, the interaction between person and machine, has received considerable attention over the past decade in the field of computing sciences. As a consequence, computing has moved from laboratories into the hands of the ordinary person - even the ordinary five-year-old. Most equity tools are an offshoot of user interfacing research and should receive the same careful attention to user interfacing standards and guidelines.

Postsecondary institutions have an important role to play in enabling people with disabilities. In the short term, they need to address directly issues of equity for people with handicaps, enabling equal access to modern technologies. Over the long term, postsecondary institutions need to ensure that all graduates in the human services area have a depth of knowledge in applying computing technologies to support the needs of people with disabilities. They also need to conduct research and disseminate information on the development of equity tools and the application of these tools. This three-tier approach to enabling people with disabilities through equity tools should benefit disabled students entering our postsecondary institutions today, those entering tomorrow, and those students preparing to enter a decade from now.

\section{References}

Alberta Education Technology in Education Committee. (1987). Visions 2000: A vision of educational technology in Alberta by the year 2000.

Alberta Education Curriculum Support Branch. (1987). A strategic plan for microcomputers in schools. 
Borow, Henry. (1979). Shifting postures toward work: A tracing. In Weinrach, S.G. (Ed.), Career counseling: Theoretical and practical perspectives. New York: McGraw-Hill Book Co.

Bromley, John \& Lakatos, John. (1985). Software tools: A one-semester secondary school computer course. The Computing Teacher, 13 (1), 4-5.

Coates, M. L. (1986). Employment equity: Issues, approaches and public policy framework. Kingston: Queen's University Industrial Relations Center.

Greene, I. (1989). The charter of rights. Toronto: James Lorimer \& Company.

Gower, David. (1988). Employment of disabled canadians. Canadian Social Trends Statistics Canada. Summer issue.

The closing the gap 1989 resource directory. (1989). Closing the Gap, 7(6), 38-179.

Keddy, Betty A. S. (1989). Methods of adapting computers for use by disabled students. Journal of Postsecondary Education and Disability, 7 (1), 17-26.

Highlights from the Canadian health and disability survey: 1983-1984. (1985). Statistics Canada, Health Division, Minister of Supply and Services Canada.

Holland, John L. (1966). The psychology of vocational choice: A theory of personality types and model environments. Waltham, Mass: Blaisdell Publishing Co.

Irons, Thomas R. (1985). Microcomputer usage for the person with a disability. Journal of Rehabilitation. Jan., 31-34.

Kulik, C. T., Oldham, G.R. and Hackman, J. K. (1987). Work design as an approach to person environment Fit. Journal of Vocational Behavior, 31(3), 278-296.

Marks, Bonnie. (1989). A computer on every teacher's desk. Update. 2(2), 1-2.

McGough, Charles S., Jungjohan, Barbara, \& Thomas, James (Eds). (1983). Directory of college facilities and services for the handicapped. Phoenix, Arizona: Oryx Press.

Moursund, Dave. (1989). Why are our colleges of education continuing to educate computer illiterate teachers? The Computing Teacher, 16(9), 4.

Moursund, Dave. (1986). The information era: What does it mean to education? The Computing Teacher, 13(5), 4-5.

Higher Education and National Affairs, 36(6), 1. Report shows increase of freshmen with disabilities. (1987).

Shell, Duane F., Horn, Christy A., \& Severs, Mary K. (1988). Effects of a computerbased educational center on disabled students' academic performance. Journal of College Student Development, 29, 432-440.

Suerko, Branimir. (1989). Origin of individual difference in importance attached to work: A model and a contribution to its evaluation. Journal of Vocational Behavior, 34(1), 28-39.

Super, Donald E. (1957). The psychology of careers: An introduction to vocational development. New York: Harper \& Row Publishers.

Toffler, Alvin. (1980). The third wave. New York: William Morrow and Company Inc.

World Health Organization. (1980) International classification of impairments, disabilities, and handicaps. Geneva: W.H.O. 